\title{
Haemodynamic effects of ketamine and thiopentone during anaesthetic induction for \\ Caesarean section
}

Raymond R. Schultetus MD PHD,

David A. Paulus MD MS, G. Lynn Spohr BSN CRNA

Ketamine (l $\left.\mathrm{mg} \cdot \mathrm{kg}^{-1}\right)$ or thiopentone $\left(4 \mathrm{mg} \cdot \mathrm{kg}^{-1}\right)$ was used to induce anaesthesia for Caesarean section in 62 normotensive patients. During induction of anaesthesia and before laryngoscopy, blood pressure did not change in either group (preinduction systolic blood pressure, $131 \mathrm{mmHg}$, and diastolic blood pressure, $75 \mathrm{mmHg}$. When laryngoscopy and intubation were performed, mean blood pressures of both patient groups increased $20-30$ per cent. With ketamine $(n=30)$ heart rate was unchanged from the preinduction rate of 85 beats/min before laryngoscopy and increased significantly by 15 per cent during laryngoscopy and intubation. With thiopentone $(n=32)$, heart rate increased significantly to 20 per cent above the preinduction rate of 87 beats/min during induction and increased further (to 35 per cent above the preinduction rate) during laryngoscopy and intubation. The average maximal rate-pressure product calculated for the thiopentone group was over 18,000, which was significantly higher than the 15,000 calculated for the ketamine group. Neonatal outcome as assessed by Apgar score and umbilical blood gas analysis was good and did not differ significantly between groups.

\section{Key words}

ANAESTHESTA: obstetric; ANAESTHETICS, INTRAVENOUS: ketamine; thiopentone, BLOOD PRESSURE: drug effects.

From the Department of Anesthesiology, College of Medicine, and the Department of Mechanical Engineering, College of Engineering, University of Florida. Presented in part at the Annual Meeting of the American Society of Anesthesiologists, New Orleans, October 1981 Address correspondence to: Dr. Schultetus, Department of Anesthesiology, Box J-254, J. Hillis Miller Health Center, Gainesville, FL 32610-0254.
Ketamine as an induction agent for Caesarean section has been either condemned for a high incidence of unpleasant dreams and increased matemal blood pressure ${ }^{\mathrm{l}, 2}$ or (with an induction dose of $1 \mathrm{mg} \cdot \mathrm{kg}^{-1}$ or less) praised for good neonatal neurobehavioural scores and low incidence of maternal intraoperative awareness. ${ }^{3,4}$ In studies of ketamine (1.2 $\mathrm{mg} \cdot \mathrm{kg}^{-1}$ or less), the incidence of unpleasant dreams was low and did not differ from that with thiopentone $\left(3 \mathrm{mg} \cdot \mathrm{kg}^{-1}\right) .{ }^{4-6}$ However, haemodynamic effects of the two agents have not been compared.

\section{Methods}

According to a research plan approved by the institutional review board, 62 unpremedicated normotensive ASA physical status I or II patients scheduled for elective Caesarean section were assigned by medical record number to receive either thiopentone $\left(4 \mathrm{mg} \cdot \mathrm{kg}^{-1}\right)(\mathrm{n}=32)$ or ketamine $\left(1 \mathrm{mg} \cdot \mathrm{kg}^{-1}\right)(\mathrm{n}=30)$. All patients were positioned with left uterine displacement and standard monitors for ECG and temperature were applied. An automatic oscillometric blood pressure monitor (Sentron-Bard Biomedical) recorded systolic, diastolic, and mean arterial pressures and heart rate every minute. ${ }^{7}$ Anaesthesia was administered by an anaesthetist blinded to the study drug. After five minutes of preoxygenation and intravenous administration of d-tubocurarine $\left(0.07 \mathrm{mg} \cdot \mathrm{kg}^{-1}\right)$, anaesthesia was induced by rapid intravenous infusion of either thiopentone or ketamine. Succinylcholine ( $2 \mathrm{mg} \cdot \mathrm{kg}^{-1} \mathrm{IV}$ ) was given for muscle relaxation and cricoid pressure was applied until the trachea was intubated. Fifty per cent nitrous oxide in oxygen 
TABLE I Values for experimental groups (mean \pm SD)

\begin{tabular}{lcc}
\hline & $\begin{array}{l}\text { Thiopentone } \\
(n=32)\end{array}$ & $\begin{array}{l}\text { Ketamine } \\
(n=30)\end{array}$ \\
\hline $\begin{array}{l}\text { Age (years) } \\
\text { Weight (kg) }\end{array}$ & $23.5 \pm 5.6$ & $22.8 \pm 4.9$ \\
$\begin{array}{l}\text { Blood pressure (mrn Hg)* } \\
\quad \text { Systolic }\end{array}$ & $129 \pm 12.9$ & $75.3 \pm 13.7$ \\
$\quad \begin{array}{l}\text { Diastolic } \\
\text { Heart rate* (beats/min) }\end{array}$ & $75 \pm 11.4$ & $76 \pm 14.5$ \\
$\begin{array}{l}\text { Induction-to-delivery } \\
\text { interval (min) }\end{array}$ & $87 \pm 13.8$ & $85 \pm 11.9$ \\
\hline
\end{tabular}

*Immediate preoperative measurements.

was administered until delivery of the foetus and a succinylcholine infusion ( 2 to $3 \mathrm{mg} \cdot \mathrm{min}^{-1}$ ) maintained relaxation. After delivery, intravenous narcotics were given as needed and 70 per cent nitrous oxide in oxygen was administered.

In the immediate pre-induction period, five consecutive measurements of blood pressure and heart rate taken at least three minutes apart were averaged for each patient (before induction). Further, blood pressure and heart rate were measured automatically every minute until delivery and at the following specific times: just after the patient lost consciousness (induction), when the trachea was being intubated (laryngoscopy and intubation), immediately after skin incision (incision), and when the foetus was removed from the uterus (delivery).

Although this was a study of maternal cardiovascular changes during anaesthetic induction, certain infant parameters were measured also. In all cases, Apgar scores, assessed by a neonatologist blinded to the study drug, were recorded. A subset of neonates within each group was selected randomly and umbilical arterial and venous blood gases and $\mathrm{pH}$ were measured.

Data were analyzed by using the unpaired $t$-test and repeated measures analysis of variance. The Bonferroni inequality was used to correct for multiple comparisons. Apgar scores were compared by using a Mann-Whitney rank-sum test. Significance was assumed for $p<0.05$.

\section{Results}

There were no significant differences between groups with respect to age, weight, preinduction blood pressure, preinduction heart rate, or induction-to-delivery interval (Table I).

Before laryngoscopy, induction of anaesthesia did not affect blood pressure in either group (Table II). However, during laryngoscopy, blood pressure increased significantly in both groups ( $p<0.05$ ): systolic pressure by 15 to 20 per cent, diastolic pressure by 25 per cent, and mean arterial pressure by 30 per cent. Blood pressure remained high during surgical incision and subsequently slowly returned toward the preinduction level.

Induction with thiopentone increased heart rate significantly $(p<0.05)$ and it increased further during laryngoscopy to 35 per cent above the preinduction level (Table III). Induction with ketamine did not affect heart rate; however, during laryngoscopy, a 15 per cent increase above the preinduction rate was recorded. From the time of induction through incision, heart rate with ketamine remained significantly lower $(\mathrm{p}<0.05)$ than that with thiopentone.

The rate-pressure product, obtained by multiplying systolic blood pressure and heart rate, increased by 60 per cent with thiopentone (from 11,000 to

TABLE II Effect of anaesthetic induction with ketamine or thiopentone on blood pressures (mean \pm SD)

\begin{tabular}{|c|c|c|c|c|c|c|}
\hline & \multicolumn{2}{|c|}{$\begin{array}{l}\text { Systolic } \\
\text { pressure }(\mathrm{mmHg})\end{array}$} & \multicolumn{2}{|c|}{$\begin{array}{l}\text { Diastolic } \\
\text { pressure (mmHg) }\end{array}$} & \multicolumn{2}{|c|}{$\begin{array}{l}\text { Mean arterial } \\
\text { pressure }(\mathrm{mm} \mathrm{Hg})\end{array}$} \\
\hline & Thiopentone & Ketamine & Thiopentone & Ketamine & Thiopentone & Ketamine \\
\hline Before induction & $129 \pm 15.3$ & $134 \pm 14.5$ & $75 \pm 11.4$ & $76 \pm 10.5$ & $93 \pm 12.6$ & $94 \pm 11.8$ \\
\hline During induction & $127 \pm 16.8$ & $131 \pm 16.9$ & $75 \pm 17.6$ & $76 \pm 13.3$ & $92 \pm 18.9$ & $97 \pm 16.1$ \\
\hline 5 min after induction & $137 \pm 17.0$ & $142 \pm 17.8$ & $81 \pm 14.9$ & $83 \pm 12.6$ & $103 \pm 17.7^{*}$ & $106 \pm 16.4^{*}$ \\
\hline Laryngoscopy and intubation & $154 \pm 23.0^{*}$ & $152 \pm 19.1^{*}$ & $98 \pm 19.6^{*}$ & $97 \pm 16.3^{*}$ & $119 \pm 21.6^{*}$ & $118 \pm 17.8^{*}$ \\
\hline Incision & $154 \pm 27.0^{*}$ & $152 \pm 16.7^{*}$ & $94 \pm 20.3^{*}$ & $92 \pm 11.5^{*}$ & $117 \pm 22.1^{*}$ & $117 \pm 14.2^{*}$ \\
\hline Delivery & $132 \pm 15.3$ & $141 \pm 16.7$ & $74 \pm 14.3$ & $80 \pm 10.0$ & $96 \pm 17.1$ & $103 \pm 12.3^{*}$ \\
\hline
\end{tabular}

*Significantly different ( $\mathrm{p}<0.05$ ) from before induction (within groups). 
TABLE III Effect of anaesthetic induction with ketamine or thiopentone on heart rate and rate-pressure product (mean \pm SD)

\begin{tabular}{|c|c|c|c|c|}
\hline & \multicolumn{2}{|c|}{ Heart rate (beats/min) } & \multicolumn{2}{|c|}{ Rate-pressure product } \\
\hline & Thiopentone & Ketamine & Thiopentone & Ketamine \\
\hline Before induction & $87 \pm 13.8$ & $85 \pm 11.9$ & $11373 \pm 2908$ & $11327 \pm 1952$ \\
\hline \multicolumn{5}{|l|}{ Induction } \\
\hline During & $104 \pm 21.0^{*} \dagger$ & $88 \pm 16.6$ & $13329 \pm 3690^{*}$ & $11384 \pm 2283$ \\
\hline After $-5 \mathrm{~min}$ & $102 \pm 18.0$ & $95 \pm 15.9$ & $13966 \pm 3348^{m}$ & $13502 \pm 3001 *$ \\
\hline Laryngoscopy and intubation & $118 \pm 19.4^{*} \dagger$ & $98 \pm 17.6^{*}$ & $18369 \pm 4679 * \dagger$ & $14958 \pm 3511^{*}$ \\
\hline Incision & $114 \pm 18.7 * \dagger$ & $100 \pm 16.3^{*}$ & $17862 \pm 5288^{*}$ & $15210 \pm 3044^{*}$ \\
\hline Delivery & $98 \pm 18.4$ & $97=17.2^{*}$ & $13072 \pm 3347^{*}$ & $13608 \pm 3121^{*}$ \\
\hline
\end{tabular}

*Significantly different ( $\mathrm{p}<0.05$ ) from before induction value (within groups).

†Significantly different from ketamine group during same sample period (between groups).

18,000). With ketamine, a 30 per cent increase above the preinduction value was calculated (from 11,000 to 15,000 ). The increase with ketamine was significantly less $(p<0.05)$ than that with thiopentone.

With respect to umbilical venous and arterial blood, $\mathrm{pH}, \mathrm{PCO}_{2}$, and $\mathrm{PO}_{2}$ values obtained for newborn infants whose mothers received thiopentone did not differ from those for infants whose mothers received ketamine (Table IV). Likewise, 1- and 5-minute Apgar scores did not differ between the groups.

None of the patients reported recall of intraoperative events or complained of unpleasant dreams or dysporia. No patient exhibited postoperative delirium.

\section{Discussion}

The cardiovascular effects of thiopentone depend on the dose, the rate of injection, and the patient's preinjection sympathetic tone and blood volume. In healthy, unstimulated, nonpregnant patients, an intravenous injection of thiopentone $\left(4 \mathrm{mg} \cdot \mathrm{kg}^{-1}\right)$ decreases blood pressure an average of eight per cent and increases heart rate by 32 per cent. ${ }^{8}$

In isolated heart-lung preparations, thiopentone depresses mycardial contractility, ${ }^{9}$ but this is not believed to cause the decrease in blood pressure that often occurs clinically. In intact animals and humans, thiopentone acts centrally to decrease vascular tone and, thus, increases vascular capacitance and decreases venous return. ${ }^{10}$ Both cardiac output and systemic blood pressure decrease. In response to the decreased blood pressure, heart rate and, possibly, systemic vascular resistance increase..$^{9,10}$
Additionally, thiopentone lessens the inhibitory effect of blood pressure on heart rate by decreasing baroreceptor sensitivity. ${ }^{11}$ This decreased sensitivity results in less vagal inhibition of heart rate at any given blood pressure and contributes to the higher heart rate during thiopentone anaesthesia.

Intravenous ketamine produces a centrally mediated, dose-related increase in blood pressure and heart rate. An injection of 1 to $2 \mathrm{mg} \cdot \mathrm{kg}^{-1}$ increases arterial blood pressure by 20 to 25 per cent and heart rate by 10 to 15 per cent, these effects peaking some two to four minutes after injection. ${ }^{2,6.12-14}$ Ketamine is believed to increase central adrenergic activity and to inhibit the vagus nerve. ${ }^{15}$ At high doses, ketamine depresses the myocardium; however, under normal clinical conditions, this effect is insignificant. $^{12}$

Thiopentone lacks analgesic properties and, in

TABLE IV Values for newborn of experimental groups

\begin{tabular}{|c|c|c|}
\hline & Thiopentone & Ketamine \\
\hline Apgar & $(n=32)$ & $(n=30)$ \\
\hline $1 \min <7$ & 6 & 11 \\
\hline$\geq 7$ & 26 & 19 \\
\hline $5 \min <7$ & 0 & 2 \\
\hline$\geq 7$ & 32 & 28 \\
\hline Umbilical artery* & $(n=22)$ & $(n=16)$ \\
\hline $\mathrm{pH}$ & $7.26 \pm 0.06$ & $7.29 \pm 0.05$ \\
\hline $\mathrm{PCO}_{2}(\mathrm{mmHg})$ & $58 \pm 10$ & $54 \pm 6$ \\
\hline $\mathrm{PO}_{2}(\mathrm{mmH})$ & $16 \pm 5$ & $17 \pm 4$ \\
\hline Umbilical vein ${ }^{*}$ & $(n=22)$ & $(n=16)$ \\
\hline $\mathrm{pH}$ & $7.33 \pm 0.07$ & $7.33 \pm 0.05$ \\
\hline $\mathrm{PCO}_{2}(\mathrm{mmHg})$ & $48 \pm 8$ & $44 \pm 8$ \\
\hline $\mathrm{PO}_{2}(\mathrm{mmHg})$ & $31 \pm 8$ & $30 \pm 8$ \\
\hline
\end{tabular}

*Mean \pm S.D. 
lower dosages, produces hyperalgesia. ${ }^{16}$ Thus, thiopentone does little to block physiologic responses to strong stimuli and may accentuate them and, thus, result in tachycardia and hypertension. For example, the stimulation of intubation increases blood pressure by 25 to 30 per cent and heart rate by 35 per cent above pre-anaesthetic values. ${ }^{17}$ Ketamine, however, is a potent analgesic, effective even at doses too low to produce unconsciousness. ${ }^{12}$ This analgesia reduces the sympathetic stimulation caused by noxious stimuli.

In this study, after induction but before the stimulation of laryngoscopy, thiopentone increased heart rate significantly over preinduction values, which probably was a response to decreased venous return as described above. The 20 to 30 per cent increase in blood pressure and further increase in heart rate that coincided with laryngoscopy likely resulted from a sympathetic response to the stimulation of laryngoscopy and intubation during light anaesthesia. Decreased baroreceptor modulation of heart rate may have augmented the tachycardia.

The cardiovascular changes observed with ketamine could be explained in either of two ways. The dosage of ketamine was relatively low $\left(1 \mathrm{mg} \cdot \mathrm{kg}^{-1}\right)$, and, therefore, ketamine could have had minimal cardiovascular effects before laryngoscopy; the increase of blood pressure and heart rate during laryngoscopy could have been a response to strong stimulation during minimal anaesthesia. The lesser increase in heart rate compared with that during anaesthesia with thiopentone may have been due to modulation by baroreceptor reflexes during laryngoscopy and intubation. Alternatively the cardiovascular changes during laryngoscopy and intubation could have been caused by ketamine itself, independent of laryngoscopy, because ketamine can increase both heart rate and blood pressure within two to four minutes after injection. We used a rapid sequence induction, therefore, laryngoscopy occurred at approximately the same time as this sympathetic response to ketamine would have occurred.

No patient reported unpleasant dreams or intraoperative awareness nor was dysphoria noted in any patient. A recent study of healthy female volunteers compared ketamine $\left(2.5 \mathrm{mg} \cdot \mathrm{kg}^{-1}\right)$ with thiopentone $\left(5.0 \mathrm{mg} \cdot \mathrm{kg}^{-1}\right)$; with ketamine, consciousness returned more slowly and was characterized by fluctuating awareness, which produced illusions rather than dreams or hallucinations. ${ }^{18}$ Ketamine induced brief "abnormalities of mental status" that disappeared as consciousness returned. In our study, patients received a lower dose of ketamine $\left(1.0 \mathrm{mg} \cdot \mathrm{kg}^{-1}\right)$ and then were anaesthetized; by the time they emerged from anaesthesia, ketamine would have been redistributed and, thus, the emergence phenomenon attributable to ketamine was circumvented.

For normotensive pregnant patients, ketamine provides cardiovascular stability; neonatal outcome is good; and the incidences of maternal awareness and emergence phenomena are low. Therefore, we think ketamine is an acceptable and useful alternative to thiopentone to induce anaesthesia for Caesarean section.

\section{References}

1 Listle B, Chang T, Chucot $L$ et al. Study of ketamine as an obstetric anesthetic agent. Am J Obstet Gynecol 1972; 113: 247-60.

2 Meer FM, Downing JW, Coleman AJ, An intravenous method of anesthesia for Caesarean section. Part II: Ketamine. Br J Anaesth 1973; 45: 191-6.

3 Hodgkinson R, Bhatt M, Kim SS, Grewal G, Marx $G F$. Neonatal neurobehavioral tests following Cesarean section under general and spinal anesthesia. Am J Obstet Gynecol 1978; 132: 670-4

4 Peltz $B$, Sinclair DM. Induction agents for Cacsarean section. Anaesthesia 1973;28: 37-42.

5 Dich-Nielsen J, Holasek J. Ketamine as induction agent for Caesarean section. Acta Anaesthesiol Scand 1982; 26: 139-42.

6 Chodoff $P$, Stella JG. Use of CI-581 a phencyclidine derivative for obstetric anesthesia. Anesth Analg 1966; 45: 527-30.

7 Green $M$, Paulus DA, Roan VP, van der AaJ. Comparison between oscillometric and invasive blood pressure monitoring during cardiac surgery. Int J Clin Monitor Comput 1984; 1: 21-6.

8 Sonntag $H$, Hellberg $K$, Schenk HD et al. Effects of thiopental (Trapanal ${ }^{\mathbb{}}$ ) on coronary blood flow and myocardial metabolism in man. Acta Anaesthesiol Scand 1975; 19; 69-78.

9 Conway $C M$, Ellis $D B$. The haemodynamic effects of short-acting barbiturates. Br J Anaesth 1969; 41: 534-42.

10 Becker KE, Tonnesen AS. Cardiovascular effects of plasma levels of thiopental necessary for anesthesia. Anesthesiology 1978; 49: 197-200. 
11 Bristow JD, Prys-Roberts C, Fisher A, Pickering $T G$, Sleight $P$. Effects of anesthesia on baroreflex control of heart rate in man. Anesthesiology 1969; 31: 422-8.

12 White $P F$, Way $W K$, Trevor $A J$. Ketamine - its pharmacology and therapeutic uses. Anesthesiology 1982; 56: 119-36.

13 Gooding JM, Dimick AR, Tavakoli M, Corssen G. A physiologic analysis of cardiopulmonary responses of ketamine anesthesia in noncardiac patients. Anesth Analg 1977; 56: 813-6.

14 Lilburn JK, Moore J, Dundee JW. Attempts to attenuate the cardiostimulatory effects of ketamine Anaesthesia 1978, 32: 499-505.

15 Traber DL, Wilson RD, Priano $L L$. The effect of alpha-adrenergic blockade on the cardiopulmonary response to ketamine. Anesth Analg 1971; 50: 737-42.

16 Clutton-Brock J. Pain and the barbiturates. Anaesthesia $1961 ; 16: 80-8$.

17 Kautto UM. Effects of precurarization on the blood pressure and heart rate changes induced by suxamethonium facilitated laryngoscopy and intubation. Acta Anaesthesiol Scand 1981; 25: 391-6.

18 Moretti RJ, Hassan SZ, Goodman LI, Meltzer HY. Comparison of ketamine and thiopental in healthy volunteers: effects on mental status, mood, and personality. Anesth Analg 1984; 63: 1087-96.
Résumé

La kétamine (1 $\left.\mathrm{mg} \mathrm{kg}^{-1}\right)$ ou le thiopentone ( $\left.4 \mathrm{mg} \cdot \mathrm{kg}^{-1}\right)$ a été utilisé comme agent d'induction chez 62 patientes normotensives devant subir une césarienne. Lors de l'induction et avant la laryngoscopie, la tension artérielle n'a pas changé dans aucun des deux groupes (la tension artérielle systolique après induction, $131 \mathrm{mmHg}$, et la pression artérielle diastolique, $75 \mathrm{mmHg}$ ). Lors de la laryngoscopie et l' intubation la tension artérielle dans les deux groupes augmenta de 20 a 30 pour cent. Avec la kétamine $(n=30)$ la fréquence cardiaque qui était de 8.5 battements/min. avant l'induction n'a pas changée lors que l'induction et avant la laryngoscopie. Cependant on observa une augmentation significative de 15 pour cent lors de la laryngoscopie et l'intubation. Avec le thiopentone $(n=32)$ la fréquence cardiaque qui était de 87 battements/min. avant l'induction augmenta significativement de 20 pour cent lors de l'induction et avant la laryngoscopie. Cette augmentation de la fréquence cardiaque atteint 35 pour cent lors de la laryngoscopie et l'intubation. Le produit de la fréquence cardiaque par la pression maximale moyenne, calculé pour le groupe thiopentone était supérieur à 18,000 , significativement supérieur à celui du groupe kétamine calculé à 15,000. Concernant les nouveaut-nés évalués par les tests d'Apgar et l'analyse des gaz sanguins du cordon ombilical le résultat final êtait considéré bon et n'a pas différé significativement entre les deux groupes. 